\title{
Density and diversity of filamentous fungi in the water and sediment of Araçá bay in São Sebastião, São Paulo, Brazil
}

\author{
Sonia Assami Doi ${ }^{1 *}$, Aline Bartelochi Pinto ${ }^{2}$, Maria Carolina Canali², Daiane Raquel Polezel ${ }^{2}$, \\ Roberta Alves Merguizo Chinellato ${ }^{3}$ \& Ana Julia Fernandes Cardoso de Oliveira ${ }^{3}$ \\ ${ }^{1}$ Universidade Estadual Paulista, Departamento de Biociências, Avenida 24 A, 1515, 13506-900, Bela Vista, Rio \\ Claro, SP, Brazil \\ ${ }^{2}$ Universidade Estadual Paulista, Rio Claro, SP, Brazil \\ ${ }^{3}$ Universidade Estadual Paulista, São Vicente, SP, Brazil \\ *Corresponding author: Sonia Assami Doi,e-mail: soniasdoi@gmail.com
}

DOI, S. A.; PINTO, A. B.; CANALI, M. C.; POLEZEL, D. R.; MERGUIZO, R. A. C.; OliVEIRA, A. J. F. C. de. Density and Diversity of Filamentous Fungi in the Water and Sediment of Araçá Bay in São Sebastião, São Paulo, Brazil. Biota Neotropica. 18(1): e20170416. http://dx.doi.org/10.1590/1676-0611-BN-2017-0416

\begin{abstract}
Araçá Bay, located in the city of São Sebastião, São Paulo, Brazil, is a protected area of substantial complexity. It represents the last remaining mangrove swamp preserve between the cities of Bertioga and Ubatuba on the northern coast of São Paulo State. This mangrove swamp has specific physical and chemical properties, and it shelters a wide variety of life, including fungi. These microorganisms are present in a variety of species with different morphophysiological features, and they have the ability to produce enzymes of biotechnological importance. The goal of this study was to quantify, isolate, and identify filamentous fungi in water and sediment samples from the Araçá Bay mangrove swamp in São Sebastião. Two samplings were performed in the summer and two were performed in the winter. The samples were collected from intertidal zones, and dissolved oxygen (DO), temperature, salinity, and pH were measured in situ. The spread plate technique was used to inoculate the samples collected on plates with a potato dextrose agar (PDA) medium. A total of 208 colonies ( 68 from water samples and 140 from sediment samples) were isolated, and they were identified based on their morphological characteristics. Filamentous fungus density was higher in the sediment than in the water, and the samplings performed in the winter revealed a higher density than those performed in the summer. Though some of the environmental parameters were not ideal for fungal development, a high quantity of growth was nevertheless observed. When the isolated colonies were analyzed, the greatest diversity and species richness were found in the summer samples. The genera identified in all of the samples were Aspergillus, Penicillium, Cladosporium, and Fusarium. The pathogenic species found from these genera were Aspergillus fumigatus, A. terreus, Penicillium citrinum, and $P$. chrysogenum. These species are also able to produce enzymes that offer a variety of applications. The fungal community described herein represents the diversity found in this mangrove swamp during the period studied. Many of the fungus species found are pathogenic and may be useful due to their ability to produce specific enzymes applicable in the biotechnological and pharmaceutical industries.
\end{abstract}

Keywords: Mangrove swamp, Environmental parameters, Mycology.

\section{Densidade e diversidade de fungos filamentosos na água e sedimento da Baía do Araçá, São Sebastião (SP), Brasil}

Resumo: A Baía do Araçá, localizada no município de São Sebastião (SP), é uma região protegida, de grande complexidade, mantendo o último remanescente preservado de manguezal entre Bertioga e Ubatuba, litoral Norte do Estado de São Paulo. Manguezal caracteriza-se com propriedades físico-químicas específicas e abriga grande diversidade de seres vivos, entre eles os fungos. Estes microrganismos apresentam grande variedade de espécies e diferentes características morfofisiológicas com capacidade de produzir algumas enzimas de importância biotecnológica. Este trabalho teve como objetivo quantificar, isolar e identificar fungos filamentosos em amostras de água e de sedimento do manguezal da Baía do Araçá, São Sebastião, (SP). Foram realizadas 2 coletas no verão e 2 no inverno na região entremarés, medidos "in situ" os parâmetros oxigênio dissolvido (OD), temperatura, salinidade e pH. Utilizou-se a Técnica "Spread Plate" para inocular os materiais coletados, em placas com meio Potato Dextrose Agar (PDA). Foram isoladas 208 colônias (68 das amostras de água e 140 das amostras de sedimento) e identificadas pelas características morfofisiológicas. As densidades de fungos filamentosos foram maiores no sedimento em relação à água e nas coletas realizadas no inverno 
demonstraram maiores densidades do que no verão. Apesar de alguns parâmetros ambientais não se apresentarem ideais para o desenvolvimento dos fungos, observou-se alta quantidade de crescimento nas amostragens. Analisando as colônias isoladas, a maior diversidade e riqueza foram observadas na amostragem coletado no verão. Foram observados os gêneros Aspergillus sp, Penicillium sp, Cladosporium sp e Fusarium sp em todas as amostragens, dos quais as espécies Aspergillus fumigatus, A. terreus, Penicillium citrinum e P. chrysogenum identificados neste trabalho são considerados patogênicos mas também são espécies capazes de produzir enzimas aplicáveis em diversas atividades. A comunidade fúngica descrita apresenta a diversidade encontrada neste manguezal em relação à variedade ambiental no período estudado, sendo que muitos apresentam patogenicidade e podem ser uteis pela sua capacidade de produzir enzimas específicas aplicáveis nos estudos biotecnológicos e farmacêuticos.

Palavras-chave: Manguezal, parâmetros ambientais, micologia.

\section{Introduction}

Brazil possesses 1,225,444 hectares (approximately $12,250 \mathrm{~km}^{2}$ ) of mangrove swamps (MMA 2010). Of these, approximately $76 \mathrm{~km}$ are located on the northern coast of São Paulo State, and $2.1 \%$ are located within the city of São Sebastião (Dias-Brito et al. 2014).

Araçá Bay is part of the Alcatrazes Municipal Environmental Protection Area as per Municipal Law No. 848/1992. It is also part of the Northern Coast Marine Protection Area as per State Law No. 53.525/2008 (PLDS/Araçá 2016). It represents the last remaining mangrove swamps on the São Sebastião coast, and it harbors high biological diversity (Amaral et al. 2010, PLDS/Araçá 2016). This region is considered to be relatively protected by its physical makeup and location. It includes a cove bordered by rocky walls and an extensive coastal plain with soft sand, which impedes the direct effects of tide-based hydrodynamic factors (Amaral et al. 2010, Alitto et al. 2016). The region is exposed to different types of human activity, including illegal occupation (Zanardi et al. 1999), domestic effluents (PLDS/Araçá 2016), underwater dredging (Gubitoso et al. 2008, Teodoro et al. 2011, PLDS/Araçá 2016), and activities in the nearby Port of São Sebastião (Amaral et al. 2010, PLDS/Araçá 2016).

Mangrove swamps are considered a transitory costal ecosystem between land environments and marine environments. They are typical of tropical and subtropical regions and are effected by tides (Schaeffer-Novelli 1995, Schaeffer-Novelli 2000, Andreote et al. 2012). Mangrove swamp conditions are conducive to the feeding, protection, and reproduction habits of many animal species, and they are considered an important environment for the transformation of organic matter into nutrients (Schaeffer-Novelli 1995, Schaeffer-Novelli 2000, Sridhar 2004). Mangrove swamps are also considered an important niche repository for fungi (Paul \& Clark 1989, Roitman et al. 1991, Nambiar \& Raveendran 2008), which play an important role in the organic matter decomposition processes present in the ecosystem (Citrón \& Schaeffer-Novelli 1983, Allsopp \& Seal 1986, Jones et al. 2009).

Hawksworth (1991) estimated that fungal diversity is represented by approximately 1.5 million species around the world; however, recent studies have reported that this amount may be ten times higher: between 3.5 and 5.1 million species (O'Brien et al. 2005).

The survival of mycobiota and their diversity are influenced by a number of abiotic factors, one of the most important of which is hydrogen concentrations, which influences fungal growth capacity and composition. Temperature, salinity, dissolved oxygen (DO) levels, and the availability and diversity of substrata are factors which may also influence fungal composition in a given environment (Jaitly \& Rai 1982, Jaitly 1987, Jones \& Alias 1997, Tucci \& Mendes 2006), as is sediment texture (Roitman et al. 1991).

The Araçá Bay mangrove swamp substratum is made of sand and mud; it is relatively compact and it includes pebbles (Amaral et al. 2010). Schaeffer-Novelli (1995) described this mangrove swamp sediment as sandy and clayey with varying features, characteristics which may result from leaf and twig decomposition in the environment, as well as from animal matter. It may also contain the products of rock decay. Different types of rocks are brought into the environment by waves, winds, costal currents, and river flows (Schaeffer-Novelli 1995).

One study found that the fungi in sediment play an important role in processing plant-based organic matter (Carlile et al. 2001) and are active in the decomposition of organic compounds in both the sediment and the water (Harley 1971, Moore-Landecker 1996). Some characteristics of the waters in the environment favor the presence and propagation of fungi. Due to their importance in the ecosystem, these fungi must be evaluated using physical, chemical, and microbiological analyses (Jaitly \& Rai 1982, Alexopoulos et al. 1996, Jones \& Alias 1997, Duke et al. 1998). Jaitly \& Rai (1982) isolated species of fungi from the Sunderbans mangrove swamp in India and found fungi that were thermophilic and thermotolerant. Their findings were based on specific parameters, including salinity, humidity, $\mathrm{pH}$, and the amount of organic matter in the region.

Fungal species diversity in the world varies by location (latitude, longitude, and altitude), as well as by depth in the case of aquatic ecosystems. There is a tendency for greater species diversity in the tropics (Shearer et al. 2007), and most fungi isolated in the tropics and subtropics are anamorphic basidiomycetes and ascomycetes (Jones \& Alias 1997, Sridhar et al. 2005). These fungi have been associated with numerous processes and functions, including organic matter decomposition (Tortora et al. 2005, Jones et al. 2009), geochemical cycles (Tortora et al. 2005), their usefulness in the pharmaceutical industry (Walsh et al. 2004), their value in the food industry (Molitoris 1995), and their utility in biotechnology (Atlas 1981, Carneiro \& Gariglio 2011, Pereira \& Freitas 2012, Houbraken et al. 2014), among other benefits (Tortora et al. 2005, Raghukumar 2008).

Some fungi are disease-causing pathogens responsible for mycoses and allergies. They are associated with diseases affecting humans, plants, and animals alike, and they are frequently detected in polluted areas (Walsh et al. 2004). However, they also produce enzymes with biotechnological applications. These microorganisms are being tested for their ability to produce enzymes, and the most frequently isolated genera are Penicillium and Aspergillus, the latter two of which are responsible for hydrocarbon assimilation (Atlas 1981). These species also degrade water and soil pollutants into less environmentally damaging forms (Vidali 2001, Novotny et al. 2004, Passos et al. 2009).

Aspergillus terreus was a fungus isolated from marine sediments and land habitats (Damare et al. 2006). It produces different secondary metabolites, but also causes infections such as aspergillosis and mycosis (Martins et al. 2005). Fungi are highly relevant for scientific research in the fields of biotechnology and bioremediation due to their potential ability to degrade organic compounds and contaminants, and they can also provide information on the environment, on biological and functional diversity, and on mangrove swamp ecosystems (Harms et al. 2011, Bonugli-Santos et al. 2015). 
The objective of this study was to analyze the density and diversity of filamentous fungus species in water and sediment samples from the Araçá Bay mangrove swamp using molecular and morphophysiological methods, and to then correlate the findings with physical and chemical factors in the winter of 2015 and the summer of 2016.

\section{Materials and Methods}

In 2015 and 2016, samplings were performed at ten sites determined using a GPS device in the intertidal region at high tide (Figure 1). Two samplings were performed in the winter dry season (June and July 2015), and two were performed in the summer rainy season (January and February 2016). The water was collected in sterilized flasks from a depth of 15 to $30 \mathrm{~cm}$, as per American Public Health Association standards (APHA, 2005). Surface sediment was collected from the same points and stored in sterile bags until processing in the Marine Microbiology Laboratory (MICROMAR), located on São Paulo State University's São Vicente campus (UNESP, São Vicente). The DO, temperature, $\mathrm{pH}$, and salinity parameters were measured on site using a HORIBA U-50 multiparameter meter (Multiparameter Water Quality).

Twenty-gram sediment aliquots were conditioned in sterile flasks to which $180 \mathrm{~mL}$ of sterile purified water was added. The samples then underwent manual agitation for 10 minutes, a process which was repeated in order to loosen any microorganisms which had adhered to grains of sediment. Once the samples had been agitated, only the supernatant was used for the microbiological analyses (Oliveira \& Pinhata 2008).

Next, $500 \mu \mathrm{L}$ of sample material was inoculated using spread plate technology and potato dextrose agar (PDA) plates, to which the antibiotic chloramphenicol was added. The samples were then incubated at room temperature $\left(25^{\circ} \mathrm{C}\right)$ for 7 to 14 days. After the incubation period, the growth of filamentous fungus colonies on the plants was determined based on the total number of mold colonies on each incubated plate (APHA 2005). These values were calculated and expressed as colony-forming units (CFUs) per $100 \mathrm{ml}\left(\mathrm{CFU} 100 \mathrm{~mL}^{-1}\right)$ in the case of the water samples and as
CFUs per $100 \mathrm{~g}\left(\mathrm{CFU} 100 \mathrm{~g}^{-1}\right)$ in the case of the sediment samples. A total of 208 colonies were isolated and re-isolated until purity was reached. Macromorphological features (color, diameter, and appearance of the colony) and micromorphological features (microstructures) were determined in order to identify the genera in a method similar to those provided by Raper \& Fennell (1977), Nelson et al. (1983), Hanlin \& Ulloa (1988), Pitt (1985), Domsch et al. (1993), Alexopoulos et al. (1996), Houbraken et al. (2014), and Talaiekhozani \& Ponraj (2015).

Based on the most commonly observed microscopic characteristics, three physiological structure clusters were established. These three characteristics were the presence of vesicle on the conidiophore ( 7 colonies with Aspergillus features) the lack of a vesicle (11 colonies with Penicillium features), and a unique conidia format ( 2 colonies), which together represented the 20 fungi which were identified at the molecular level in the Microbiology Laboratory at the Center for Social Insect Studies at São Paulo State University's Rio Claro Campus (UNESP Rio Claro). The DNA was extracted and amplified using the polymerase chain reaction (PCR) technique. The genomic DNA was then sequenced using a modified version of the extraction technique method with cationic hexadecyl trimethyl ammonium bromide (CTAB), and two different nuclear DNA markers (LSU and ITS) were amplified for phylogenetic analysis (Möller et al. 1992). The PCR products were cleaned using a Wizard ${ }^{\circledR}$ SV Gel and PCR Clean-Up System (Promega). The cycle sequencing reactions were performed using a BigDye Terminator v.3.1 Cycle Sequencing Kit (Life Technologies), and the sequences were generated using an Applied Biosystems ${ }^{\circledR} 3500$ genetic analyzer (Life Technologies). The contigs were assembled in the BioEdit sequence alignment editor, version 7.1.3 (Hall 1999) and were consulted in GenBank from the National Center for Biotechnology Information (NCBI).

The statistical analysis was performed using the Past software. To determine the normality of the data, the Kruskal-Wallis test was applied at a 95\% significance level $(\mathrm{p}<0.05)$. Spearman's correlation test was used to correlate the non-parametric data on the environmental parameters and fungus density. Fungus species diversity and richness were determined using the Shannon diversity index $(\mathrm{H})$ and the Chao 1 estimator, respectively.

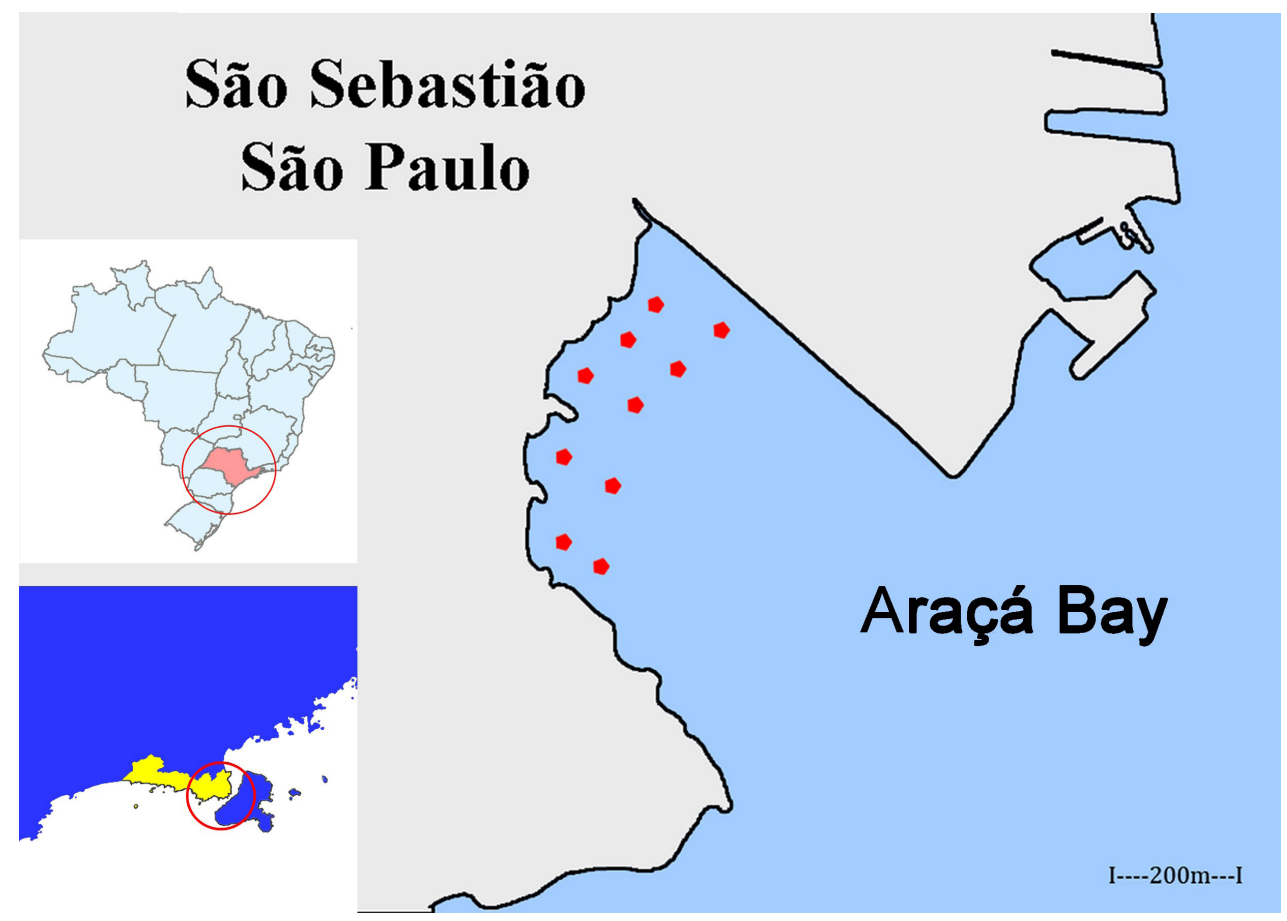

Figure 1. Map showing the research site and sampling points in the Araçá Bay mangrove swamp in the city of São Sebastião, São Paulo, Brazil. 


\section{Results and Discussion}

Certain physical and chemical aspects of the environment, including temperature and $\mathrm{pH}$, are important for the survival, adaptability, and growth of microorganisms (Jaitly 1987, Jones \& Alias 1997, Raghukumar 2008). In this study, overall average temperature was $26^{\circ} \mathrm{C}$. During the winter, this average was lower $\left(23^{\circ} \mathrm{C}\right)$, and in the summer, it reached $27.7^{\circ} \mathrm{C}$ (Table 1). According to Kohlmeyer (1983) and Wong et al. (1998), the temperatures measured in this study favor fungal diversity and reproduction: these authors report that temperature affects the distribution and diversity of filamentous fungi, and that there is greater diversity in tropical areas than in temperate waters. In addition, marine fungi require temperatures between $25^{\circ} \mathrm{C}$ and $30^{\circ} \mathrm{C}$ to reproduce (Griffin 1981).

The $\mathrm{pH}$ levels detected herein remained slightly alkaline and ranged only from 7.7 to 8.1 during the study period (Table 1). This finding is consistent with the values reported by Sengupta \& Chaudhuri (1995), who detected an alkaline $\mathrm{pH}$ ranging from 7.2 to 8.0 and who reported on filamentous fungi in mangrove swamp sediments from the Ganges River in India. Extracellular enzyme production and growth by marine fungi was described by Raghukumar et al. (2004), who reported a pH between 7 and 8. Jaitly (1987), Alexopoulos et al. (1996) and Raghukumar (2008) report that the best $\mathrm{pH}$ for the growth of different types of land fungi ranges from 4 to 7 (in the neutral to acidic range).

The salinity levels detected in this study remained below 30 ; the water can therefore be classified as brackish as per Brazil's National Environment Council (CONAMA) Resolution No. 357 from March 2005. The values did not vary substantially over the course of the study and ranged from 24.8 to 28.1 (Table 1). Duke et al. (1998), Bunt (1999), and Mueller \& Bills (2004) report that salinity is a very important ecological parameter which is directly correlated with species distribution in mangrove swamps. Though Mueller \& Bills (2004) describe salinity as a limiting factor for fungus growth, high fungal density was observed in the current study. Lorenz \& Molitoris (1992) found that the ideal salinity level for the growth of certain marine fungi increases as incubation temperature increases, a finding which indicates that Araçá Bay exhibits ideal parameters for mycological development.

The DO values $\left(\mathrm{mg} \mathrm{L}^{-1}\right)$ ranged from 4.0 to 6.7 , with a mean value of 5.5 (Table 1). In most of the samples, dissolved oxygen values remained within the limits established by CONAMA Resolution No. 357/2005 for high-quality brackish waters. Most fungi are aerobic or microaerophilic; however, some species have been found to have a limited anaerobic metabolism, and few are capable of completely anaerobic growth (Tabak \& Cooke 1968, Tortora et al. 2005). Mangrove swamps typically exhibit low levels of oxygen (Schaeffer-Novelli 1995); however, most of the samples from the Araçá Bay mangrove swamp were found to exhibit good DO quality. Because oxygen is considered an essential element for aerobic fungi, the environment analyzed herein may be considered favorable for the development of these microorganisms.

Based on the samplings, filamentous fungus colony density was found to range from $0.1 \times 10^{4} \mathrm{CFU} 100 \mathrm{~mL}^{-1}$ to $4.6 \times 10^{4} \mathrm{CFU} 100 \mathrm{~mL}^{-1}$ in the water and from $0.4 \times 10^{4} \mathrm{CFU} 100 \mathrm{~g}^{-1}$ to $42.5 \times 10^{4} \mathrm{CFU} 100 \mathrm{~g}^{-1}$ in the sediment. Density varied considerably between the two materials. The samplings performed in the summer produced lower values both in the water $\left(0.2 \times 10^{4} \mathrm{CFU} 100 \mathrm{~mL}^{-1}\right)$ and in the sediment $\left(0.9 \times 10^{4} \mathrm{CFU} 100 \mathrm{~g}^{-1}\right)$. In the winter, the highest density was found in a sediment sample: $42.5 \times 10^{4}$ CFU $100 \mathrm{~g}^{-1}$ (Table 1). Pupin \& Nahas (2014) analyzed dry sand from the swamp on Cardoso Island and determined the number of CFUs to be between $5.2 \times 10^{5} \mathrm{~g}^{-1}$ and $9.7 \times 10^{5} \mathrm{~g}^{-1}$, higher values than those obtained in the current study.

Filamentous fungus density was found to be much higher a total mean in the sediment samples and relative to the winter in the case of both the water samples and the sediment samples (Figure 2). Based on Spearman's correlation test, the statistical analysis did not reveal any significant correlations between the environmental parameters and fungal density in the water $(p>0.05)$; however, the amount of fungi in the sediment was found to be significantly and positively correlated with salinity and temperature ( $p=0.032$ and $p=0.024$, respectively). In this study, filamentous fungus colony density in the sediment was significantly higher than in the water $\left(\mathrm{p}<0.05\right.$; non-parametric Kruskal-Wallis test $\left.=9.8 \times 10^{-8}\right)$.

Similar findings were reported by Gomes et al. (2011), who analyzed filamentous fungi isolated from sediment collected from a mangrove swamp in Barra das Jangadas, Pernambuco, Brazil. The authors reported a higher incidence of fungi during the dry season $(77 \%)$ relative to the rainy season (23\%) and found that the species Aspergillus terreus, A. niger, Penicillium sp., and Trichoderma sp. were common in both seasons (Gomes et al. 2011). Pinto et al. (1992) also found that rainfall significantly increases the amount of isolated fungi in both land and aquatic ecosystems.

The colonies isolated were first identified based on macromorphological and micromorphological features (Figure 3). A total of 208 filamentous fungus colonies with different morphological features were isolated, 68 of which were from water samples and 140 of which were from sediment samples. In addition to anamorphs, a total of 15 genera were found: Aspergillus, Aureobasidium, Chaetomium, Cladosporium, Curvularia, Fusarium, Geotrichum, Mucor, Paecilomices, Penicillium, Rhizophus, Sporothrix, Talaromyces, Trichophyton, Trichoderma.

Of the fungi isolated, Aspergillus and Penicillium were the most commonly observed genera overall (38.9\% and $35.0 \%$, respectively). In the water, the genus Aspergillus was the most common (39.7\%), while in the sediment, Penicillium was the most common (42.8\%), followed by the other genera at lower frequencies (Figure 4). The colonies that were found in the asexual reproductive stage or for which microscopically differentiating features could not be detected were treated as anamorphs.

Table 1. Environmental parameters obtained from mangrove swamp samplings from Araçá Bay on the northern coast of São Paulo State, Brazil. Temp. (Temperature in ${ }^{\circ} \mathrm{C}$ ),

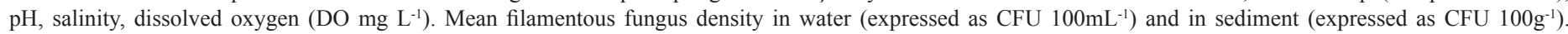
Min - Minimum value; Max = maximum value; $\mathrm{x}$ - mean; $\mathrm{s}$ - Standard deviation.

\begin{tabular}{|c|c|c|c|c|c|c|c|}
\hline \multirow{2}{*}{ samples } & \multirow{2}{*}{ Environmental parameters } & \multicolumn{2}{|c|}{ Total } & \multicolumn{2}{|c|}{ Summer } & \multicolumn{2}{|c|}{ Winter } \\
\hline & & $\min -\max$ & $\mathbf{x} \pm \mathbf{s}$ & $\min -\max$ & $\mathbf{x} \pm \mathbf{s}$ & $\min -\max$ & $\mathbf{x} \pm \mathbf{s}$ \\
\hline \multirow[t]{5}{*}{ water } & Temp. $\left({ }^{\circ} \mathrm{C}\right)$ & $22.6-31.6$ & $26.2 \pm 2.9$ & $24.3-31.6$ & $27.7 \pm 3.0$ & $22.6-25.4$ & $23.9 \pm 1.0$ \\
\hline & $\mathrm{pH}$ & $7.7-8.1$ & $7.9 \pm 0.1$ & $7.7-8.0$ & $7.9 \pm 0.1$ & $7.8-8.1$ & $8.0 \pm 0.1$ \\
\hline & salinity & $24.8-28.1$ & $27.0 \pm 0.7$ & $24.8-27.5$ & $26.6 \pm 0.7$ & $27.1-28.0$ & $27.4 \pm 0.3$ \\
\hline & $\mathrm{DO}\left(\mathrm{mg} \mathrm{L}^{-1}\right)$ & $4.0-6.7$ & $5.5 \pm 0.8$ & $4.0-6.5$ & $5.1 \pm 0.7$ & $5.3-6.7$ & $6.2 \pm 0.4$ \\
\hline & Filamentous fungus $\left(\times 10^{4} \mathrm{UFC} 100 \mathrm{~mL}^{-1}\right)$ & $0.1-4.6$ & $0.3 \pm 0.8$ & $0.1-1.1$ & $0.2 \pm 0.2$ & $0.1-4.6$ & $0.5 \pm 1.3$ \\
\hline sediment & Filamentous fungus $\left(\times 10^{4} \mathrm{UFC}_{\left.100 \mathrm{~g}^{-1}\right)}\right.$ & $0.4-42.5$ & $5.0 \pm 10.2$ & $0.4-2.0$ & $0.9 \pm 0.4$ & $0.5-42.5$ & $10.4 \pm 14.1$ \\
\hline
\end{tabular}



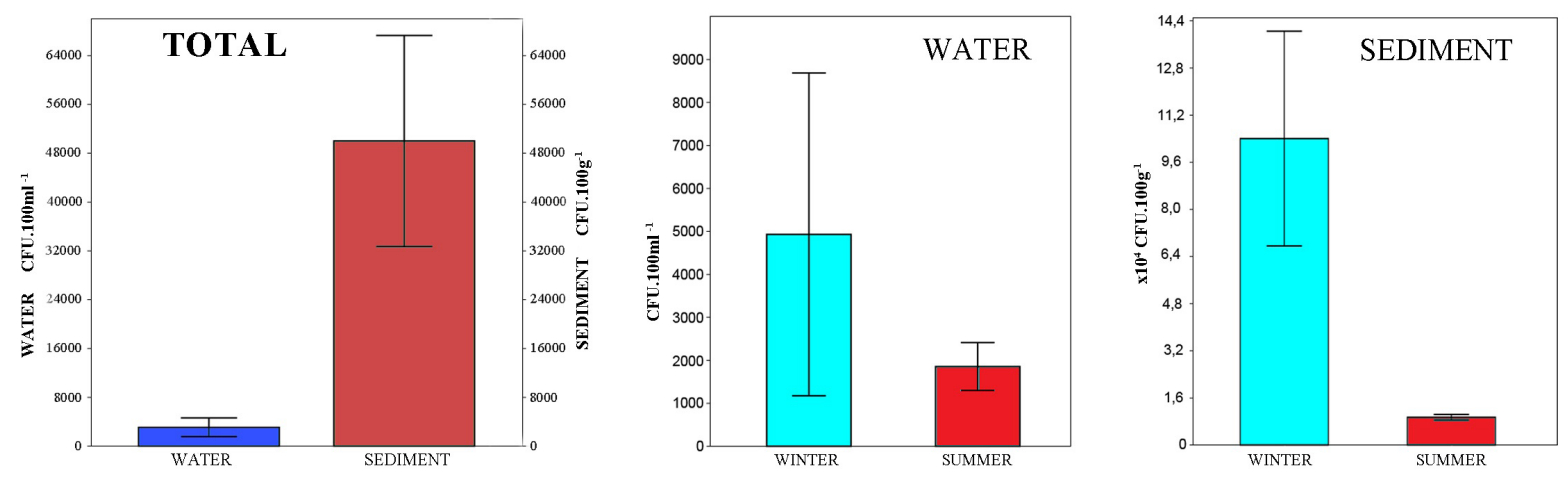

Figure 2. Mean filamentous fungus colony densities TOTAL - overall mean including the water and sediment samples; WATER (expressed as CFU 100 $\mathrm{mL}^{-1}$ ); SEDIMENT (expressed as $\times 10^{4} \mathrm{CFU} 100 \mathrm{~g}^{-1}$ ); comparisons between the seasons.

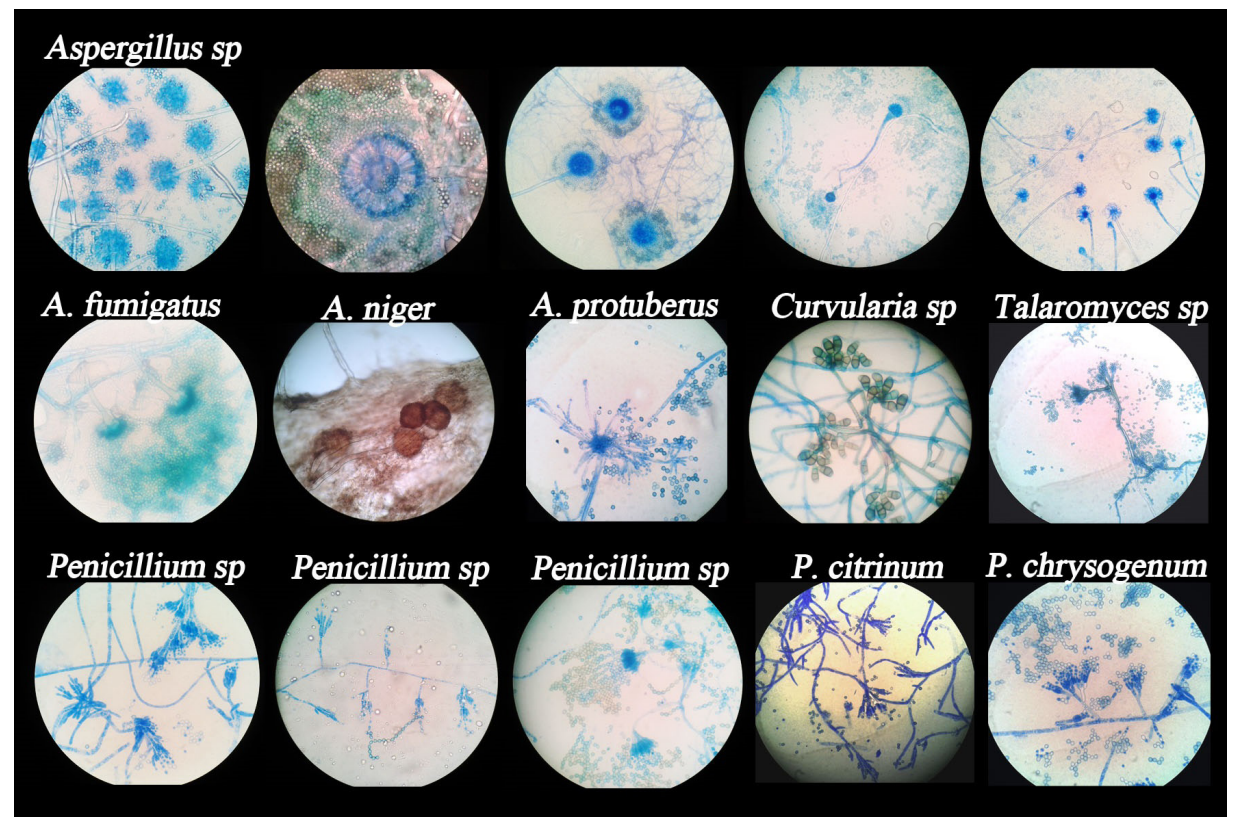

Figure 3. Isolated filamentous fungi observed microscopically.

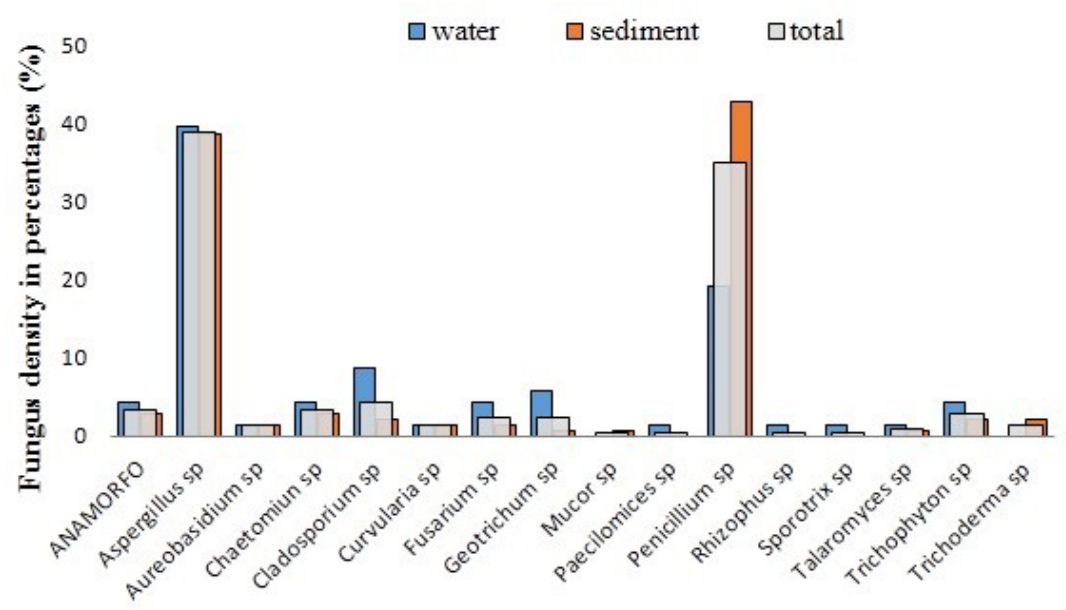

Figure 4. Percentage of filamentous fungus genera identified morphologically in samples isolated from water and sediment. 
Most fungal species were observed in both materials sampled, but the genera Paecilomices, Rhizophus, and Sporothrix were found only in the water samples, and Mucor and Trichoderma were found only in the sediment samples.

From the colonies which had been clustered based on micromorphological characteristics, 20 fungus samples were selected for DNA extraction, amplification, and sequencing for molecular identification. Of these 20 samples, 7 had Aspergillus features, 11 had Penicillium features, and 2 had unique conidia. Based on the sequencing and GenBank results, 2 samples were identified as Aspergillus fumigatus, 2 samples were identified as $A$. protuberus, 1 sample was identified as $A$. terreus, 4 samples were identified as Penicillium citrinum, 5 samples were identified as P. chrysogenum, 1 sample was identified as Talaromyces flavus, 1 sample was identified as Cladosporium sp., 2 samples were identified as Penicillium sp., and 2 samples were identified as Aspergillus sp.

In the water, the genus Aspergillus was dominant in the winter, representing $54.5 \%$ of the specimens found, followed by Penicillium at $25.0 \%$. In the summer, $20.8 \%$ of the specimens found in the water were determined to be from the genus Cladosporium, and $12.5 \%$ were found to be from the genus Aspergillus. In the sediment, the most commonly detected genera in the winter were Penicillium (47.2\%) and Aspergillus (40.8\%), and the most commonly detected genera in the summer sediment were Aspergillus (20.0\%), Cladosporium (13.3\%), and Trichoderma (13.3\%). The genus Aureobasidium was detected in both the water and the sediment and only in the summer (Figure 5).

Similar results were reported by Gomes et al. (2008), who analyzed water with high salinity and alkaline $\mathrm{pH}$ from Casa Caiada Beach in Orlinda, Pernambuco State, Brazil. They isolated 50 species of fungi, the most common of which were from the genera Aspergillus and Penicillium. In another study by Gomes et al. (2001), Penicillium was the most diverse genus in the dry season sediment collected from the Barra das Jangadas swamp in Pernambuco State. Sengupta \& Chaudhuri (1995) isolated fungi from the sediment and from an estuary of the Ganges River in India. The most commonly found genera were Aspergillus and Penicillium, though the salinity levels found were lower (11 to 15 ) than those detected in the current study.

Gomes et al. (2008) analyzed water and sediment from a beach in Olinda, Pernambuco, in both the dry season and the rainy season. They most frequently isolated and identified Aspergillus, Penicillium, and anamorphs, followed by other genera, including Fusarium, Trichoderma, Cladosporium, Curvularia, and Paecilomyces. Rai et al. (1981) isolated 87 saprobic fungi from mangrove swamp wood in India. The most common ascomycetes were from the genus Chaetomium, the most common anamorphs were from the genus Aspergillus, and other frequently isolated genera included Trichoderma, Pestalotiopsis, Curvularia, Fusarium, and Penicillium. In southern India, water samples, sediment samples, and some aquatic organisms were collected, and different Aspergillus species were identified. These included Aspergillus flavus, A. fumigatus, A. nidulans, A. niger, A. terreus, and A. terricola (Babu et al. 2010).

Fungi from the genus Cladosporium are distributed worldwide and may be isolated from a variety of substrata, including water and sediment (Gomes et al. 2008), as well as from aquatic environments (Xiong et al. 2009, Silveira et al. 2013). Mbata (2008) isolated filamentous fungi from deep and highly saline marine waters. The species found included Chaetomium globosum, Aspergillus versicolor, Hortaea wemeckii, and Aureobasidium pullulans. A. pullulans is known to be distributed in marine environments with varying environmental conditions, and this species may be used in a variety of biotechnological applications (Liu et al. 2008) due to its ability to produce enzymes such as protease, lipase, and cellulase (Chi et al. 2009).

In Brazil, Paecilomyces fungi have been isolated from the sands of Ipanema Beach in Rio de Janeiro (Sarquis \& Oliveira 1996), from the water and sediment on a beach in Olinda, Pernambuco (Gomes et al. 2008), and in the water from an estuary of the Patos Lagoon in the state of Rio Grande do Sul (Silveira et al. 2013). Richards et al. (2012) have described this genus as representing species of marine fungi, and Marante et al. (2012) isolated a new strain of Paecilomyces variotti from a marine environment, a strain which they determined was able to produce bioactive compounds.

Some of the fungi identified in the current study are known for being pathogenic. These include Aspergillus fumigatus, A. terreus (Martins et al. 2005, Walsh et al. 2008), Penicillium chrysogenum (Barcus et al. 2005), and

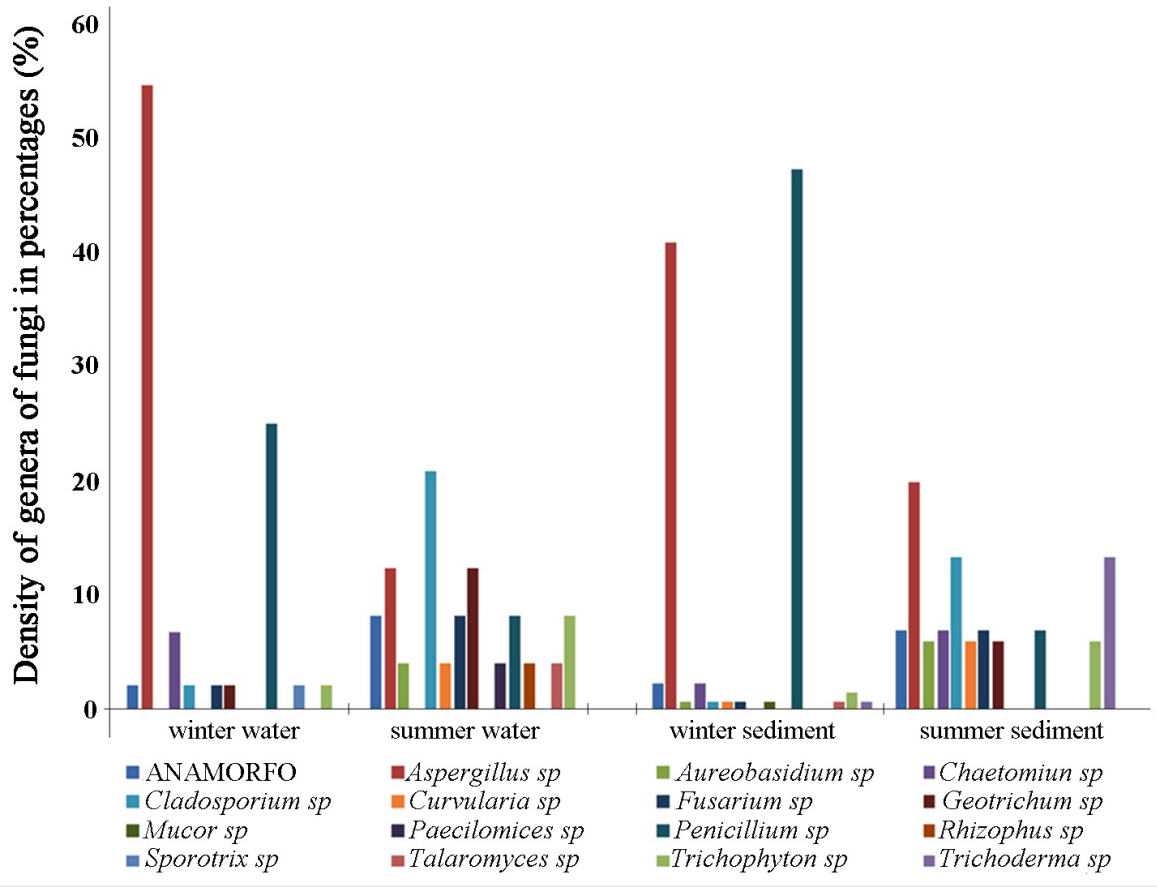

Figure 5. Filamentous fungus densities expressed as percentages (\%) in water and sediment samples in the winter and summer. 
Penicillium citrinum (Houbraken et al. 2010). Other studies have reported that some filamentous fungi are able to produce and assimilate enzymes for biotechnological applications. These genera include Aspergillus and Penicillium, which have proven to be important producers of enzymes such as cellulase (Zhang \& Kim 2010, Castillo et al. 1994), xylanase (Zhang \& Kim 2010, Shah \& Madamwar 2005), lipase (Sharma et al. 2005, Zhu et al. 2009), and amylase (Prabakaran et al. 2009, Mishra \& Dadhich 2010). The species Aspergillus fumigatus and A. terreus have been reported to have the potential to degrade hydrocarbon (Atlas 1981, Chaillan et al. 2004). Penicillium chrysogenum is able to produce amylase (Prabakaran et al. 2009, Silva et al. 2011) and alkaline protease (Zhu et al. 2009). Finally, P. citrinum has been found to produce both lipase (Silva et al. 2009) and cellulase (Santos et al. 2017).

In the current study, the greatest diversity was observed in the summer sediment $\left(H^{\prime}=2.4\right)$, followed by the summer water $\left(H^{\prime}=2.1\right)$, the winter sediment $\left(H^{\prime}=1.2\right)$, and finally, the winter water, in which the lowest diversity was detected $\left(H^{\prime}=0.9\right)$. According to Piedras et al. (2006), Shannon's diversity index may provide information on conservation and impacted environments. These authors also note that values between 1.0 and 3.0 reflect moderately polluted water, indicating that the region analyzed herein exhibits a good level of diversity relative to the environment. According to the Chao 1 estimator, the summer water sample exhibited the highest level of species richness among the samples (Chao 1=12). Though the summer sediment samples exhibited the highest level of diversity in this study, the water samples collected in the summer exhibited the highest amount of species richness. These findings indicate that analyses performed on summer samples may provide more information on these fungi.

Sebastianes et al. (2013) reported that the richness and diversity of endophytic fungi on leaves and branches in São Paulo swamps were higher in the summer than in the winter, results which are consistent with those of the current study. Maria \& Shidhar (2003) also analyzed wood from costal mangrove swamp in southeast India and found more fungal diversity in the rainy season than in the dry season. In the study by Yadav et al. (2016), season had a significant influence over the diversity of endophytic fungi: the highest species diversity was detected during the rainy season, while the lowest was detected during the dry season. However, their data on fungal species diversity was not found to correlate with the number of isolates found in each season.

Fungi isolated from environments with extreme variations in temperature and salinity are likely to exhibit physiological adaptations that allow them to tolerate or even affect the availability of other substances in the environment (Damare et al. 2006, Stoeck et al. 2003). Studies have noted the potential of fungi from marine ecosystems to have biotechnological applications after evaluating fungal diversity and the role of fungi in the bioremediation of pollutants in contaminated environments (Gaylard et al. 2005, Passos et al. 2009, Pereira \& Freitas 2012, Bonugli-Santos et al. 2015). Filamentous fungi have been found to be very effective in removing heavy metals from aqueous solutions due to their greater resistance to these elements (Kurek et al. 1982, Collins \& Stotzky 1992).

\section{Conclusion}

The isolation of filamentous fungi from habitats such as mangrove swamps, which exhibit a complex variety of physical and chemical characteristics, can aid in the determination of their biological diversity and their ability to survive under adverse conditions. This knowledge may improve our understanding of the distribution of these microorganisms and their interactions with their ecosystems, as well as the human impact on these organisms, their role in conservation, and their use in a range of preservation and remediation processes. Many of the fungi found in this study may serve as potential indicators in biotechnological processes.

The preservation of these microbial communities is beneficial for biodiversity and is an important factor in sustaining ecosystems. Furthermore, studies on diversity may help us to clarify information on native microorganisms, on biological changes associated with environmental damage, and on how to protect plants specifically and ecosystems as a whole.

\section{Acknowledgments}

The authors would like to thank UNESP CLP, Marine Microbiology Laboratory (MICROMAR) and UNESP Rio Claro, Microbiology Laboratory at the Center for Social Insect Studies. The Brazilian National Research Council (CNPq) and São Paulo Research Foundation (FAPESP) are acknowledged for financial support: The Biota Araçá Research Project (process number: 2011/50317-5).

\section{Author Contributions}

Sonia Assami Doi and Ana Julia Fernandes Cardoso de Oliveira: substantial contribution to the concept and design of the study; contribution to data collection, data analysis and interpretation; contribution to manuscript preparation and critical revision.

Aline Bartelochi Pinto: substantial contribution to the concept and design of the study: contribution to manuscript preparation and critical revision.

Maria Carolina Canali, Daiane Raquel Polezel and Roberta Alves Merguizo Chinellato: contribution to data collection, data analysis and interpretation.

\section{Conflicts of interest}

The authors declare that they have no conflict of interest related to the publication of this manuscript.

\section{References}

ALEXOPOULOS, C.J.; MIMS, C.W. \& BLACKWELL, M. 1996. Introductory Mycology. 4ed. New York: John Wiley \& Sons. 869p.

ALITTO, R.A.dosS.; BUENO, M.L.; DIDOMENICO, M. \& BORGES, M. 2016. Annotated checklist of Echinoderms from Araçá Bay, Southeastern Brazil. Check List, The Journal of Biodiversity Data. v.12, n.1, article 1836.

ALLSOPP, D. \& SEAL, K.J. 1986. Introduction to Biodeterioration. London, Edward Arnold. 133p.

AMARAL, A.C.Z.; MIGOTTO, A.E.; TURRA, A. \& SCHAEFFER-NOVELLI, Y. 2010. Araçá: biodiversidade, impactos e ameaças. Biota Neotrópica. 10(1): p.219-264.

ANDREOTE, F.D.; JIMÉNEZ, D.J.; CHAVES, D.; DIAS, A.C.; LUVIZOTTO, D.M.; DINI-ANDREOTE, F.; FASANELLA, C.C.; LOPEZ, M.V.; BAENA, S.; TAKETANI, R.G. \& DEMELO, I.S. 2012. The microbiome of Brazilian mangrove sediments as revealed by metagenomics. PLoS One, 7(6):e38600.

APHA, American Public Health Association. 2005. Standard Methods for the Examination of Water and Wastewater. APHA, AWWA, WEF. $21^{\text {th }}$ Edition.

ATLAS, R.M. 1981. Microbial degradation of Petroleum Hydrocarbons - an Environmental Perspective. Microbial Review: 180-209.

BABU, R.; VARADHARAJAN, P.; SOUNDARAPANDIAN, D. \& BALASUBRAMANIAN, R. 2010. Fungi diversity in different coastal marine ecosystem along South East Coastal of India. Microbiol. Research. v.1, n.3, p.175-178.

BARCUS, A.L.; BURDETTE, S.D. \& HERCHLINE, T.E. 2005. Intestinal invasion and disseminated disease associated with Penicillium chrysogenum. Ann Clin Microbiol Antimicrob. v 4, n.21, p.1-4.

BONUGLI-SANTOS R.C.; VASCONCELOS, M.R.DosS.; PASSARINI, M.R.Z.; VIEIRA, G.A.L.; LOPES, V.C.P.; MAINARDI, P.H.; DOSSANTOS, J.A.; DUARTE, L.DeA.; OTERO, I.V.R.; YOSHIDA, A.M.DaS.; FEITOSA, V.A.; PESSOA Jr, A. \& SETTE, L.D. 2015. Marine-derived fungi: diversity of enzymes and biotechnological applications. Front. Microbiol. 6:269. doi: 10.3389/ fmicb.2015.00269

BUNT, J.S. 1999. Overlap in mangrove species zonal patterns: some methods of analysis. Mangroves and Salt Marshes, 3: p.155-164.

CARLILE, M.J.; WATKINSON, S.C. \& GOODAY. G.W. 2001. The fungi, 2nd ed. Academic Press, San Diego. 558 p. 
CARNEIRO, D.A. \& GARIGLIO, L.P. 2011. A biorremediação como ferramenta para a descontaminação de ambientes terrestres e aquáticos. Revista Tecer. v.3(4), p.82-95

CASTILLO, M.R.; GUTIERREZ-CORREA, M.; LINDEN, J.C. \& TENGERDY, R.P. 1994. Mixed culture solid substrate fermentation for cellulolytic enzyme production. Biotechnology Letters, 16, p.967-972.

CHAILLAN, F.; FLÈCHE, A LE.; BURY, E.; PHANTHAVONG, Y.; GRIMONT, P.; SALIOT, A. \& OUDOT, J. 2004. Identification and biodegradation potential of tropical aerobic hydrocarbon degrading microorganisms. Research in Microbiology, v.155, p.587-595.

CHI, Z.; WANG, F.; CHI, Z.; YUE, L; LIU, G. \& ZHANG, T. 2009. Bioproducts from Aureobasidium pullulans, a biotechnologically important yeast. Applied Microbiology and Biotechnology, 82, p.793-804.

CINTRÓN, G. \& SCHAEFFER-NOVELLI, Y. 1983. Introduccion a la ecologia del manglar. Montevidéu, Unesco/Rostlac, 109p.

COLLINS, Y. E. \& STOTZKY, G. 1992. Heavy metals alter the electrokinetic properties of bacteria, yeast and clay minerals. Applied and Environmental Microbiology, New York, v.58, n.5, p.1592-1600

CONAMA. Ministério do Meio Ambiente. Conselho Nacional do Meio Ambiente. 2005. Resolução $n^{\circ} 357$, do dia 17 de março de 2005. Dispõe sobre a classificação dos corpos de água e diretrizes ambientais para seu enquadramento, bem como estabelece as condições e padrões de lançamento de efluentes, e dá outras providencias. Diário Oficial da República Federativa do Brasil, Brasília, DF, p. 208-303.

DAMARE, S.; RAGHUKUMAR, C. \& RAGHUKUMAR, S. 2006. Fungi in deep-sea sediments of the Central Indian Basin. Deep-Sea Res. I. 53, p.14-27.

DIAS-BRITO, D.; MILANELLI, J.C.C.; RIEDEL, P.S. \& WIECZOREK, A. 2014 Sensibilidade do litoral paulista a derramamentos de petróleo: um atlas em escala de detalhe. $1^{\circ}$ ed. Rio Claro: UNESP, 238p.

DOMSCH, K.H.; GAMS, W. \& ANDERSON, T.H. 1993. Compendium of soil fungi. Eching: IHW-Verlag, v. 1, 860p.

DUKE, N.C.; BALL, M.C. \& ELLISON, J.C. 1998. Factors influencing in mangroves biodiversity and distributional gradients, Global Ecology and Biogeography Letters, 7: p.27- 47.

GOMES, D.N.F.; CAVALCANTI, M.A.Q.; FERNANDES, M.J.S.; LIMA, D.M.M. \&; PASSAVANTE, J.Z.O. 2008. Filamentous fungi isolated from sand and water of "Bairro Novo" and "Casa Caiada" beaches, Olinda, Pernambuco, Brazil. Braz. J. Biol., 68(3): p.577-582.

GOMES. D.N.F; CAVALCANTI, M.A.de \& PASSAVANTE, J.Z.deO. 2011. Fungos filamentosos isolados de sedimento do manguezal barra das Jangadas, Jaboatão dos Guararapes, Pernambuco, Brasil. Tropical Oceanography, Recife, v. 39, n. 1, p.69-78.

GRIFFIN, D.H. 1981. Fungal Physiology. Canada: John Wiley \& Sons. 383p

GUBITOSO, S.; DULEBA, W.; TEODORO, A.C.; PRADA, S.M.; DAROCHA, M.M.; LAMPARELLI, C.C.; BEVILACQUA, J.E. \& MOURA, D.O. 2008. Estudo geoambiental da região circunjacente ao emissário submarino de esgoto do Araçá, São Sebastião (SP). Revista Brasileira de Geociências, v.38 (3), 38(3): p.467-475

HALL, T.A. 1999. BioEdit 5.0.9: A user-friendly biological sequence alignment editor and analysis program for Windows 95/98/NT. Nucleic Acids Symposium Series, 41, p.95-98.

HANLIN, R.T. \& ULLOA, M. 1988. Atlas of Introductory Mycology. Hunter Textbooks. 2ed. 196p.

HARLEY, JL. 1971. Fungi in Ecosystems. J. Appl. Ecol., vol. 8, no. 3, p.627-642.

HARMS, H.; SCHOLOSSER, D. \& WICK, L.Y. 2011. Untapped potential: exploiting fungi in bioremediation of hazardous chemicals. Nature Reviews Microbiology, London, v.9, p.177-192.

HAWKSWORTH, D.L. 1991. The fungal dimension of biodiversity: magnitude, significance, and conservation. Mycological Research, 95(6), p.641-655.

HOUBRAKEN, J.; DE VRIES, R.P. \& SAMSON, R.A. 2014. Modern taxonomy of biotechnologically important Aspergillus and Penicillium species. Adv Appl Microbiol.; 86:p.199-249.

HOUBRAKEN, J.A.M.P.; FRISVAD, J.C. \& SAMSON, R.A. 2010. Taxonomy of Penicillium citrinum and related species. Fungal Diversity. v.44, p.117-133.

JAITLY, A.K. \& RAI, J.N. 1982. Thermophilic and thermotolerant fungi isolated from mangroves swamps. Mycologia, 6: 74, p.1021-1022.

JAITLY, A.K. 1987. pH optima of the fungi isolated from mangroves soils in India. Transactions of the Mycological Society of Japan, 28, p.137-143.
JONES, E.B.G. \& ALIAS, S.A. 1997. Biodiversity of Mangrove Fungi. In: Biodiversity of Tropical Microfungi. University Press. Hong Kong, p.71-92.

JONES, E.B.G.; SAKAYAROJ, J.; SUETRONG, S.; SOMRITHIPOL, S. \& PANG, K.L. 2009. Classification of marine Ascomycota, anamorphic taxa and Basidiomycota. Fungal Diversity.v.35: p.1-187.

KOHLMEYER, J. 1983. Geography of marine fungi. Aust. J. Bot. Suppl. Ser. 10 p.67-76.

LIU, Z.; WANG, L.; CHI, Z. \& LI, J. 2008. Production, purification and characterization of an extracellular lipase from Aureobasidium pullulans HN2.3 with potential application for the hydrolysis of edible oils. Biochemical Engineering Journal, 40, p.445-451

LORENZ, R. \& MOLITORIS, H.P. 1992. Combined influence of salinity and temperature (Phoma-pattern) on growth of the marine fungi. Canadian Journal of. Botany 70: p.2111-2115.

MARANTE, F.J.T.; MIOSO, R.; BARRERA, J.B.; GONZÁLEZ, J.E.G.; RODRIGUEZ, J.J.S. \& LAGUNA, H.B. 2012. Structural characterization and metabolite profiling of the facultative marine fungus Paecilomyces variotti. Ann Microbiol. v.62, issue 4, p.1601-1607.

MARIA, G.L. \& SRIDHAR, K.R. 2003. Diversity of filamentous fungi on wood litter of five mangrove plant species from the southwest coast of India. Fungal Diversity 14: p.109-126.

MARTINS, J. E.C.; MELO, N.T. \& HEINS-VACCARI, E.M. 2005. Atlas de Micologia Médica, Editora Manole Ltda. 170 p.

MBATA, T.I. 2008. Isolation of fungi in hyper saline Dead Sea water. Sudanese. Journal of Public Health, v.3, p.170-172.

MISHRA, B.K. \& DADHICH, S.K. 2010. Production of Amylase and Xylanase Enzymes from soil Fungi of Rajasthan. J. Adv. Dev. Res.. v.1, v.1, p.21-23

MMA. 2010. Gerência de Biodiversidade Aquática e Recursos Pesqueiros. Panorama da conservação dos ecossistemas costeiros e marinhos no Brasil. Brasília: MMA/ SBF/GBA, $148 \mathrm{p}$.

MOLITORIS, H.P. 1995. Fungi in biotechnology: Past, present, future. CZECH Mycolol.v.48(1), p.53-65.

MÖLLER, E.M.; BAHNWEG, G.; SANDERMANN, H. \& GEIGER, H.H. 1992. A simple and efficient protocol for isolation of high molecular weight DNA from filamentous fungi, fruit bodies, and infected plant tissues. Nucleic Acids Res 20: p.6115-6116.

MOORE-LANDECKER, E. 1996. Fundamentals of the fungi. New Jersey: Prentice Hall Inc. 574 p.

MUELLER, G.M. \& BILLS, G.F. 2004. Introduction. In: Mueller, GM, Bills, GF, Foster, MS. (eds). Biodiversity of fungi: inventory and monitoring methods. Elsevier Academic Press, San Diego, p.1-4.

NAMBIAR, G.R. \& RAVEENDRAN, K. 2008. Marine and manglicolous marine fungal diversity in coastal wetlands of Kerala. Seaweed Res. Utiln. v.30: p.55-61.

NELSON, P.E.; TOUSSOUN, T.A. \& MARASAS, W.F.O. 1983. Fusarium species: An illustrated manual for identification. University Park: The Pennsylvania State University Press. 193p.

NOVOTNY, C.; SVOBODOVA, K.; ERBANOVA, P.; CAJTHAML, T.; KASINATH, A.; LANG, E. \& SASEK, V. 2004. Ligninolytic fungi in bioremediation: extracellular enzyme production and degradation rate. Soil biology \& biochemistry. 36: p.1545-1551

O'BRIEN, H.E.; PARRENT, J.L.; JACKSON, J.A.; MONCALVO, J.M. \& VILGALYS R. 2005. Fungal community analysis by large-scale sequencing of environmental samples. Applied and Environmental Microbiology, 71(9), p.5544-5550.

OLIVEIRA, A.J.F.C. \& PINHATA, J.M.W. 2008. Antimicrobial resistance and species composition of Enterococcus spp. isolated from waters and sands of marine recreational beaches in Southeastern Brazil. Water Research, 42(8-9), p.2242-50.

PASSOS, C.T.; BURKERT, J.F.M.; KALIL, S.J. \& BURKERT, C.A.V. 2009 Biodegradação de fenol por uma nova linhagem de Aspergillus sp. isolada de um solo contaminado do sul do Brasil. Química Nova, v.32, n.4, p.950-954.

PAUL, E.A. \& CLARK, F.E. 1989. Soil Microbiology and Biochemistry. San Diego, Academic Press. 273p.

PEREIRA, A.R.B. \& FREITAS, D.A.F.de 2012. Uso de microrganismos para a biorremediação de ambientes impactados. Rev. Elet. em Gestão, Educação e Tecnologia Ambiental. v.6, n.6, p.995-1006.

PIEDRAS, S.R.N.; BAGER, A.; MORAES, P.R.R.; ISOLDI, L.A.; FERREIRA, O.G.L. \& HEEMANN, C. 2006. Macroinvertebrados bentônicos como indicadores de qualidade de água na barragem Santa Bárbara, Pelotas, RS, Brasil. Ciência Rural, v.36(2), p.494-500. 
PINTO, I.M.A.; CAVALCANTI, M.A.Q. \& PASSAVANTE, J.Z.deO. 1992. Hongos filamentosos aislados desde el suelo y el agua en la playa de Boa Viagem (RecifeBrasil). Bol. Micológico, v.7, n.1-2, p.39-45.

PITT, J.I. 1985. A laboratory guide to common Penicillium species. Academic Press, Australia, 182p.

PLDS/Araçá. 2016. Plano Local de Desenvolvimento Sustentável da Baía do Araçá. Org.: TURRA, A.; SANTOS, C.R.; PERES, C.M.; SEIXAS, S.C.; SHINODA, D.C.; STORI, F.T.; XAVIER, L.Y.; ANDRADE, M.M.; SANTANA, M.F.M.; RODRIGUES, M.V.; GRILLI, N.M.; JACOBI, P.R.; SARAFINI, T.Z. 1a Edição. São Paulo: Instituto Oceanográfico da Universidade de São Paulo, 69p.

PRABAKARAN, M.; THENNARASU, V.; MANGALA, R.A.; BHARATHIDASAN, R.; CHANDRAKALA, N. \& MOHAN, N. 2009. Comparative studies on the enzyme activities of wild and mutant fungal strains isolated from sugarcane field. Indian J Sci Technol. 2(11), p.46-49.

PUPIN, B. \& NAHAS, E. 2014. Microbial populations and activities of mangrove, restinga and Atlantic forest soils from Cardoso Island, Brazil. Journal of applied microbiology, 116 (4), p.851-864.

RAI, J.N.; GARG, K.L. \& JAITLY, A.K. 1981.Saprophytic fungi isolated from woods in mangrove swamps and their wood-decaying capability. Transactions of the Mycological Soc. of Japan 22: p.65 - 74.

RAGHUKUMAR, C.; RAGHUKUMAR, S.; SHEELU, G.; GUPTA, S.M.; BAGENDER, B. \& RAO, B.R. 2004. Buried in time: culturable fungi in a deep-sea sediment core from the Chagos Trench, Indian Ocean. Deep Sea Res 51, p.1759-1768.

RAGHUKUMAR, C. 2008. Marine fungal biotechnology: an ecological perspective. Fungal Diversity, v.31, p.19-35.

RAPER, K.B. \& FENNELL, D.I. 1977. The genus Aspergillus. Huntington: Robert E. Krieger. 686p.

RICHARDS, T.A.; JONES, M.D.M.; LEONARD, G. \& BASS, D. 2012. Marine Fungi: Their Ecology and Molecular Diversity. Annu. Rev. Marine. Sci., 4: p.495-522.

ROITMAN, I.; TRAVASSOS, L.R. \& AZEVEDO, J.L. 1991. Tratado de Microbiologia. Editora Manole, São Paulo, v. 2. 126p.

SALLENAVE-NAMONT, C.; POUCHUS, Y.F.; ROBIOU DU PONT, T.; LASSUS, P. \& VERBIST, J.F. 2000.Toxigenic saprophytic fungi in marine shellfish farming areas. Mycopathologia. v.149, n.1, p.21-25.

SANTOS, D.A.; OLIVEIRA, M.M.; CURVELO, A.A.S.; FONSECA, L.P. \& PORTO, A.L.M. 2017. Hydrolysis of cellulose from sugarcane bagasse by cellulases from marine-derived fungi strains. International Biodeterioration \& Biodegradation, v.121, p.66-78

SARQUIS, M.I.M. \& OLIVEIRA, P.C. 1996. Diversity of microfungi in the Sandy soil of Ipanema Beach, Rio de Janeiro, Brazil. J. Basic. Microbiol., v.36, n.1, p.51-58.

SCHAEFFER-NOVELLI, Y. 1995. Manguezal: Ecossistema entre a terra e o mar. São Paulo. Caribbean Ecological Researcjh. 64p.

SCHAEFFER-NOVELLI, Y. 2000. Manguezal, os dispositivos legais como instrumento da conservação. In V Simpósio de Ecossistemas Brasileiros: Conservação e Duna. ACIESP, São Paulo, p.10-17.

SEBASTIANES, F.L.De.S.; ROMÃO-DUMARESQ, A.S.; LACAVA, P.T.; HARAKAVA, R.; AZEVEDO, J.L.; DEMELO, I.S. \& PIZZIRANI-KLEINER, A.A. 2013. Species diversity of culturable endophytic fungi from Brazilian mangrove forests. Curr Genet. 59:p.153-166.

SENGUPTA, A. \& CHAUDHURI, S. 1995. Ecology of microfungi in mangroves sediments at the Ganges river estuary in Índia. Indian Forester, v.121, issue 9, p. $807-812$

SHAH, A.R. \& MADAMWAR, D. 2005. Xylanase production by a newly isolated Aspergillus foetidus strain and its characterization. Process Biochemistry, v.40, p.1763-1771.

SHARMA, R.; CHISTI, Y. \& BANERJEE, Y.C. 2005. Production, purification, characterization and applications of lipases. Biotechnology Advances. v.19, n.8, p.627-662.

SHEARER, C.; DESCALS, E.; KOHLMEYER, B.; KOHLMEYER, J.; MARVANOVÁ, L.; PADGETT, D.; PORTER, D.; RAJA, H.A.; SCHMIT, J.P.; THORTON, H.A. \& VOGLYMAYR, H. 2007. Fungal biodiversity in aquatic habitats. Biodiversity and Conservation, v. 16, p.49-67.

SILVA, D.C.V.; TIAGO, V.P.; MATOS, J.L.S.; PAIVA, L.M. \& SOUZA-MOTTA, C.M. 2011. Isolamento e seleção de fungos filamentosos do solo de sistemas agroflorestais do Município de Bom Jardim (PE) com base na capacidade de produção de enzimas hidrolíticas. Revista Brasil. Botânica, v.34, n.4, p.607-610.
SILVA, G.S.; BRUNO, L.M. \& CASTRO, H.F. 2009. Seleção e Imobilização de Fungos Filamentosos Produtores de Lipase Intracelular. Quim. Nova, Fortaleza, v. 5, n. 8, p.01-07.

SILVEIRA, E.S.; LOBATO, R.C. \& ABREU, P.C. 2013. Fungos e Leveduras no Estuário da Lagoa dos Patos e Praia do Cassino, RS, Brasil. Atlântica, Rio Grande, 35(1), p.45-54,

SRIDHAR, K.R. 2004. Mangrove fungi in India. Current Science, v.86, n,12, p.1586-1587.

SRIDHAR, K.R. 2005. Diversity of fungi in mangrove ecosystems. In: Satyanarayana,T.; Johri, B.N. (ed.). Microbial diversity: Current perspectives and potential applications. I.K. International Publishing House Pvt. Ltd. p.129-148.

STOECK, T.; TAYLOR, G.T. \& EPSTEIN, S. 2003. Novel eukaryotes from the permanently anoxic Cariaco Basin (Caribbean Sea). Applied and Environmental Microbiology 69: p.5656-5663.

TABAK, H. \& COOKE, W.B. 1968. Growth and metabolism of fungi in an atmosphere of nitrogen. Mycologia. v.60, n.1, 115-140.

TALAIEKHOZANI, A. \& PONRAJ, M. 2015. Identification of Molds \& Bacteria made Easier for Engineers. Lambert Academic Publishing. 72p.

TEODORO, A.C.; DULEBA; W. \& GUBITOSO, S. 2011. Estudo multidisciplinar (geoquímica e associações de foraminíferos) para caracterizar e avaliar intervenções antrópicas na Baía do Araçá, Canal de São Sebastião, SP. Geologia USP. Série Científica 11(1): p.113-136.

TORTORA, G.J.; FUNKE, B.R. \& CASE, C.L. 2005. Microbiologia. Ed. Artmed. Porto Alegre, $8^{\text {a }}$ ed. 182p

TUCCI, C.E.M. \& MENDES, C.A. 2006. Avaliação Ambiental Integrada de Bacia Hidrográfica. Ministério do Meio Ambiente, Brasília. 302p.

VIDALI, M. 2001. Biorremediation: an overview, Journal of Applied Chemistry, v.73, n.7, p.1163-1172.

WALSH, T.J.; ANAISSIE, E.J.; DENNING, D.W.; HERBRECHT, R.; KONTOYIANNIS, D.P.; MARR, K.A.; MORRISON, V.A.; SEGAL, B.H.; STEINBACH, W.J.; STEVENS, D.A.; BURIK, J.Van; WINGARD, J.R. \& PATTERSON, T.F. 2008. Infectious diseases society of America. Treatment of aspergillosis: clinical practice guidelines of the Infectious Diseases Society of America. Clinical Infectious Diseases. v.46, p.327-360.

WALSH, T.J.; GROLL, A.; HIEMENZ, J.; FLEMING, R.; ROILIDES, E. \& ANAISSIE, E. 2004. Infections due to emerging and uncommon medically important fungal pathogens. Clinical Microbiology and Infection, v.10, Issue s1, p.48-66.

WONG, M.K.M.; GOH, T.K.; HODGKISS, I.J.; HYDE, K.D.; RANGHOO, V.M.; TSUI, C.K.M.; HO, W.H.; WONG, W.S.W. \& YUEN, T.K. 1998. Role of fungi in freshwater ecosystems. Biodiversity and Conservation, v. 7, p.1187-1206.

XIONG, H.; QI, S.; XU, Y.; MIAO, L. \& QIAN, P.Y. 2009. Antibiotic and antifouling compound production by the marine-derived fungus Cladosporium sp. F14. Journal of Hydro-environment Research. v.2, p.264-270.

YADAV, M.; YADAV, A.; KUMAR, S. \& YADAV, J.P. 2016. Spatial and seasonal influences on culturable endophytic mycobiota associated with different tissues of Eugenia jambolana Lam. and their antibacterial activity against MDR strains. BMC Microbiology. 16:44, p.1-12.

ZANARDI, E.; BÍCEGO, M.C.; DEMIRANDA, L.B. \& WEBER. R.R. 1999. Distribution and origin of hydrocarbons in water and sediment in São Sebastião, SP, BR. Marine Pollution Bulletin 38(4): p.261-267.

ZHANG, C. \& KIM, S.K. 2010. Research and Application of Marine Microbial Enzymes: Status and Prospects. Mar. Drugs. V.8, p.1920-1934.

ZHU, H.Y.; TIAN, Y.; HOU, Y.H. \& WANG, T.H. 2009. Purification and characterization of the cold-active alkaline protease from marine cold-adaptive Penicillium chrysogenum FS010. Mol. Biol. Rep. v.36(8), p.2169-2174.

Received: 01/08/2017

Accepted: 05/01/2018

Published online: 01/02/2018 